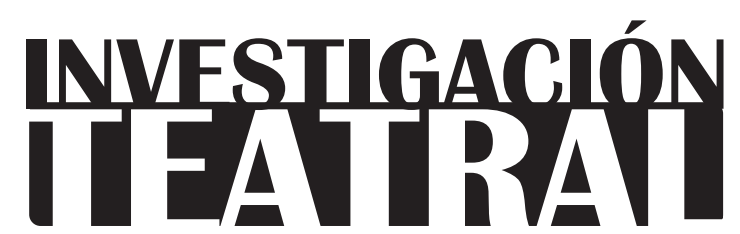

Revista de artes escénicas y performatividad

Vol. 11, Núm. 17

abril-septiembre 2020

Segunda época

ISSN impreso: 1665-8728

ISSN electrónico: 2594-0953

Universidad Veracruzana

La parodia, la sátira y la intertextualidad:

las diferencias y

afinidades entre Las

fábulas perversas, de

Óscar Liera, y 1822, de Flavio González Mello

Ricardo Torres Miguel*

\footnotetext{
* Universidad Autónoma Metropolitana-Iztapalapa, México.

e-mail:ricksabato@gmail.com
}

Recibido: 15 de agosto de 2019

Aceptado: 11 de marzo de 2020

Doi: $10.25009 /$ it.v11i17.2627 


\title{
La parodia, la sátira y la intertextualidad: las diferencias y afinidades entre Las fábulas perversas, de Óscar Liera, y 1822, de Flavio González Mello
}

\section{Resumen}

El teatro histórico ha tenido pocos exponentes en la escena mexicana de los últimos años. Los dramaturgos Óscar Liera y Flavio González Mello figuran entre los pocos que han representado con maestría este género teatral. Las fábulas perversas fue una de las creaciones finales de Liera, en la que parodia al célebre fraile Servando Teresa de Mier. Por su parte, González Mello retomó el tema del fraile dominico en 1822, obra que aborda el año en que México fue imperio. Ambos textos tienen como protagonista al polémico personaje, sólo que en la versión de Liera se plantea al religioso por medio de la parodia, mientras que la de Mello se centra en la sátira.

Palabras clave: historia, memoria colectiva, independencia, parodia, México.

\section{Parody, Satire and Intertextuality: Differences and Affinities between Óscar Liera's Las fábulas perversas and Flavio González Mello's 1822}

\begin{abstract}
Although historical theater in Mexico has been scarce in recent years, playwrights Óscar Liera and Flavio González Mello are among the few who brilliantly address this genre. Las fábulas perversas (Perverse Fables) is one of Liera's final plays, where he parodies Friar Servando Teresa de Mier, a historical character also found in González Mello's 1822, a piece that addresses the year in which Mexico was an empire. In both texts the controversial friar is protagonist, only that in the Liera version he is depicted through parody, while in Mello's play Teresa de Mier is given a satirical treatment.
\end{abstract}

Keywords: history, collective memory, independence, parody, Mexico. 


\section{La parodia, la sátira y la intertextualidad: las diferencias y afinidades entre Las fábulas perversas, de Óscar Liera, y 1822, de Flavio González Mello}

$\mathrm{E}$ teatro hstórico ha tenido pocos exponentes tan brillantes como Óscar Liera y Flavio González Mello. En México, el primero corresponde a lo que se llamó la "Nueva dramaturgia", según se señala en el libro del mismo nombre de Vicente Leñero; es, tal vez, la figura ulterior monumental de las artes escénicas, a las cuales contribuyó con innumerables obras que destacaron, sobre todo, por su aguda forma de ver la realidad mexicana. Las fábulas perversas $(1988)^{2}$ fue una de sus creaciones finales, en la que aborda una de sus obsesiones preferidas: la corrupción entre la Iglesia y el Estado, al colocar como protagonista al célebre fray Servando Teresa de Mier. En el otro caso, González Mello retomó las peripecias del fraile dominico con 1822 (publicada en 2004). ${ }^{3,}{ }^{4}$ Curiosamente, en ambos textos se tiene como protagonista a Teresa de Mier, sólo que en la pieza de Liera se representa al religioso por medio de la parodia, mientras que González Mello se centra más en la sátira y en la precisión histórica.

1 Este trabajo contó con la beca para estancia posdoctoral del Consejo Nacional de Ciencia y Tecnología (Conacyt).

2 La primera publicación fue en 1988, en la revista Artes Escénicas, año 1, número 5, con la presentación de Esther Seligson, aunque el estreno de Las fábulas perversas se efectuó antes, por el Tatuas, el 2 de septiembre de 1986 y fue dirigida por Soledad Ruiz (Liera 118).

3 Obra en la que se aborda el año en que México fue imperio, es decir, la etapa después de la obtención de su independencia Se estrenó en mayo de 2002. Fue producida por la UNAM, en colaboración con el INBA, y se publicó dos años más adelante (De la Rosa 76).

4 N. del Ed.: La obra de teatro llevó por título 1822. El año que fuimos imperio y fue estrenada en el teatro Juan Ruiz de Alarcón del Centro Cultural Universitario (UNAM), bajo la dirección de Antonio Castro. 
Más allá de la simple coincidencia entre estas obras, es importante analizar aspectos tales como personajes, trama e ideología para comprobar si pudiera haber más que una relación fortuita, una situación de intertextualidad. Por ello, el objetivo central de este trabajo será estudiar las concordancias entre los personajes, los temas y los momentos de la historia, con la visión netamente intertextual. Como hipótesis, es posible señalar que el teatro histórico en México - reciente- ha preferido representar temas cruciales de su historia, como lo son la Independencia o la Revolución, tal vez por ser momentos clave o por ser etapas incómodas para algunos mexicanos. En el caso de Liera, la dramaturgia se caracteriza por hacer uso de la parodia, mientras que González Mello opta más por la sátira en algunas de sus tramas, lo cual hace que sus textos tengan una intención reflexiva, casi didáctica, como si se utilizara con el fin de dejar una enseñanza o una postura sobre el evento histórico. ${ }^{5}$ Anteriormente cité que sus obras no sólo se remiten a un pasado remoto, sino también a un presente inmediato, pues están formuladas para entender la realidad de la época que estaban viviendo los autores, pero de eso se leerá más adelante.

\section{Origen y aplicación del término intertextualidad}

El origen del término intertextualidad, como tal, proviene de Julia Kristeva quien, influida por Mijaíl Bajtín, menciona: "todo texto se construye como mosaico de citas, todo texto es absorción y transformación de otro texto. En el lugar de la noción de intersubjetividad se instala la de intertextualidad, y el lenguaje poético se lee, por lo menos, como doble" (3). Más adelante, la escritora búlgara-francesa afirmará que: "El interlocutor del escritor es, pues, el escritor mismo en su calidad de lector de otro texto. El que escribe es el mismo que lee. Siendo su interlocutor un texto, él mismo no es sino un texto que se relee reescribiéndose" (21). Estas

5 A propósito de esta afirmación sobre el teatro y su función educativa, Juan Lucas Onieva señala lo siguiente: "las dramatizaciones desarrollaban un pensamiento histórico y un nivel de comprensión conceptual superior en comparación con otras clases en las que se impartía la materia con recursos más convencionales y de forma tradicional" (citado en Latapí 195). En una sintonía similar, Alicia Martín López y Pablo Álvarez Domínguez indican cómo contribuye la enseñanza del teatro en la escuela: “[...] gracias al teatro tenemos la oportunidad de innovar en el aula universitaria, posibilitando que el alumnado interiorice el conocimiento de una manera más práctica, se divierta, se relacione con otros, se disfrace, pierda la vergüenza y la timidez, abra su mente, adopte actitudes empáticas, desarrolle un aprendizaje cooperativo, dialogue con el pasado desde el presente, etc." (citado en Latapí 196). Aunque en nuestro caso no se incluye la enseñanza del teatro en la escuela, coincidimos en que el arte dramático potencia el aprendizaje de diversas disciplinas como la historia, pues provoca un diálogo y una reflexión. Asunto que empata con la intención didáctica de Liera y Mello en las obras estudiadas. 
citas sintéticas acerca de cómo la filósofa percibe a la intertextualidad no tendrían al parecer mayor problema, pues su análisis acepta la huella de un libro en otro ulterior. Incluso, si se compara con la definición de Gérard Genette, "una relación de copresencia entre dos o más textos, es decir, eidéticamente y frecuentemente, como la presencia efectiva de un texto en otro" (10), tampoco afectaría una comprensión correcta del concepto.

En todos estos planteamientos teóricos es indudable que el lector/espectador sea tomado en cuenta para poder formular una situación de intertextualidad:

El receptor de un texto debe ser capaz de descubrir la red intertextual del texto para interpretarlo, para conseguir una interpretación coherente. Partimos de la idea de que un texto no es coherente per se. Es el lector/oyente (espectador) el que confiere coherencia a un texto. Ello implica dos tipos de operaciones: establecer relaciones entre las partes de un texto; y, establecer una conexión entre el texto y la propia experiencia del mundo, incluyendo la experiencia de textos previos, lo que conlleva determinar qué concepción del mundo presupone el texto. Así pues, para hallar coherencia en un texto el receptor debe establecer una conexión entre el texto y los esquemas que hay en su mente (Luzón 137).

De esta manera, el receptor es quien da sentido al texto, ya sea como referencia, cita o alusión. Hay que tomar en cuenta que nos referimos a un lector especializado para poder leer las referencias, pues se requiere un horizonte de expectativas amplio. ${ }^{6}$

Otro teórico que abordó el tema de la intertextualidad, desde la perspectiva del lector, fue Roland Barthes quien, en su célebre ensayo La muerte del autor, da cuenta de la ruptura de la voz autoral al cederle todo el reconocimiento al texto, el cual es creado por "un tejido de citas provenientes de los mil focos de la cultura" (343). De esta manera, al igual que Bajtín y Kristeva, Barthes confirma que todo texto proviene de otro, incluso mayor que él, pues en aras de introducir una multiplicidad, su relación puede darse con otras referencias de la cultura, como puede ser la música o la pintura. Así, nuevamente, es notable la visión de darle el derecho al lector de ser el último eslabón en esta cadena, es decir, de ser quien logre darle vida al texto.

6 Aquí la explicación de cómo la recepción de un texto se relaciona con la intertextualidad: "El hecho intertextual se vincula con los estudios de la recepción; cada hecho intertextual concreto se manifiesta primero en el texto -o sea, en la obra de creación, según la intencionalidad del autor- y se aprecia, especialmente, en la recepción y en el efecto estético y/o cognitivo que produce en el lector que identifica las relaciones intertextuales, es decir que reconoce las conexiones entre distintas obras o que asocia referencias, indicios o peculiaridades que aparecen en distintas obras de las que el lector tiene conocimiento y experiencia" (Mendoza párrafo 11). 
Es evidente que, tanto Kristeva, Genette, Luzón, Barthes y Jesús Camarero coinciden en que la intertextualidad propone un diálogo entre obras y autores con el fin de señalar que la cultura es una compleja red de referencias que completan lo que hoy podría entenderse como una multidisciplinariedad artística. Es responsabilidad del lector/espectador poder decodificar dicha red.

Explicado lo anterior, es menester apuntar que la intertextualidad en Las fábulas perversas y en 1822 funciona a través de la similitud en la configuración de los protagonistas (fray Servando), el tema histórico (la Independencia de México) y, sobre todo, los recursos metodológicos afines que ambas obras usan. Esto sucede porque en la obra de Liera se utiliza la parodia para representar a un fray Servando Teresa de Mier de tipo jocoso y burlón; por otro lado, González Mello crea a un fray Servando de tono satírico, muy similar al de Las fábulas perversas, por lo que consideramos que, en 1822, hay la plena intención de aludir a la obra del dramaturgo sinaloense. Además, existen situaciones parecidas entre las obras, como lo son: personajes, momentos e, incluso, escenas. Por ello, el interés de este trabajo es mostrar cómo la conexión entre estas piezas se debe a un complejo tejido de estrategias literarias que necesitan explicarse, para demostrar una filiación directa entre estas dos obras.

\section{¿Qué es la parodia y su relación con la intertextualidad y la sátira?}

Linda Hutcheon señala que la parodia está íntimamente ligada a la intertextualidad, en cuanto que forma parte de sus tantas funcionalidades. Ella la define de la siguiente manera:

Como las otras formas intertextuales (la alusión, el pastiche, la cita, la imitación y demás), la parodia efectúa una superposición de textos. En el nivel de su estructura formal, un texto paródico es la articulación de una síntesis, una incorporación de un texto parodiado (de segundo plano) en un texto parodiante, un engarce de lo viejo en lo nuevo. Pero este desdoblamiento paródico no funciona más que para marcar la diferencia: la parodia representa a la vez la desviación de una norma literaria y la inclusión de esta norma como material interiorizado. No está de más insistir sobre la especifidad literaria y textual de la parodia a causa de la confusión crítica que la rodea (177).

La investigadora canadiense, una de las teóricas más importantes en cuanto al estudio de la parodia, señala que el término bien puede entenderse como "un acuerdo, una intimidad y no un contraste" (178). En muchos casos, se puede entender más como un homenaje que como burla. De esta premisa, se puede comprender la parodia como una herramienta dialógica que 
conversa con sus receptores y los alienta a buscar nuevas vías de significación, no sólo para juzgar el proceso intertextual, sino para explicar las convergencias entre los textos.

$\mathrm{Al}$ respecto, Jesús Camarero da una definición similar a la de Hutcheon:

La parodia tiene cierta relación con el pastiche (al cual engloba en la tradición clásica) y supone la imitación de un estilo (puede ser una cita transcrita con un ligero desvío), poniendo subrayadamente de manifiesto la relación entre el texto anterior o antiguo (en general ya canonizado) y el texto moderno o nuevo, es una especie de caricatura de una obra anterior o una reutilización de la misma para transponerla o sobrepasarla, dentro de un juego que puede ser lúdico, subversivo o admirativo, y su efecto, en muchas ocasiones, suele ser percibido despectivamente con un juicio peyorativo. La parodia consiste en la transformación de un texto cuyo tema es modificado conservando su estilo, y su eficacia aumenta cuanto más cerca se reescribe el hipertexto (el texto paródico) del hipotexto (el texto parodiado); por ello, es normalmente bastante breve, ya que el montaje de citas no es soportado durante una gran cantidad de texto (39).

Por otro lado, la diferencia entre la parodia y la sátira reside en que la segunda:

[...] es la forma literaria que tiene como finalidad corregir, ridiculizándolos, algunos vicios e ineptitudes del comportamiento humano. Las ineptitudes a las que de este modo se apunta están generalmente consideradas como extratextuales en el sentido en que son, casi siempre morales o sociales y no literarias (Hutcheon 178).

Para la línea de trabajo que se sigue en este texto, es preciso señalar que las definiciones de Hutcheon y Camarero son útiles porque la parodia y la sátira suelen tener diversos matices, es decir, "según la finalidad que se han planteado los distintos autores, la parodia puede derivar hacia la sátira, la deformación caricaturesca y/o grotesca o tener un fin meramente humorístico o lúdico, con una amplia gama de matices intermedios" (Ivanov párrafo 14).

En cuanto a Las fábulas perversas el acto paródico, a su vez, tiene dos funciones; en un primer caso, es la burla hacia diversos personajes que, usualmente, son una deformación grotesca de sus contrapartes originales; en otro aspecto, la parodia se torna más hacia el homenaje de cierta figura histórica y de respeto, esto es fray Servando Teresa de Mier, personaje principal de la obra de Liera. Los dos usos de la parodia son igualmente importantes en el desarrollo de esta obra, pero llama la atención la caracterización de Servando (parodia de fray Servando) quien, como protagonista, se muestra como un ser comprometido, valiente, inteligente y, sobre todo, rebelde, lo cual denota una notable admiración de Liera con el fraile dominico. 
En cuanto a 1822, la sátira se centra en ridiculizar a sus contrapartes históricos; sin embargo, González Mello también opta por darle cierta seriedad al personaje de Teresa de Mier. En ambas piezas, este personaje podrá verse tanto como un héroe que defiende los ideales del ser humano contra las imposiciones eclesiásticas, así como una especie de antihéroe que se rebela contra los patrones de la Iglesia y del Estado. El objetivo será descubrir la relación entre el fray Servando de Las fábulas perversas y el de 1822, pues el de Liera, por su naturaleza, irá más en camino hacia la parodia, y el de Mello más hacia la sátira, con claros tintes políticos y sociales. Un primer acercamiento será decir que la obra de Liera es el hipotexto, en palabras de Genette, y la de González Mello, el hipertexto, esto es, el texto que aprovecha las alusiones, citas y referencias de la obra de Liera. ${ }^{7}$ De tal suerte que en González Mello encontramos una significación más seria de muchos de los artilugios que teníamos en Liera; uno de ellos será la crítica a la historia, pero también a la actualidad que cada uno enfrentó con su texto. ${ }^{8}$ Todo esto dicho de manera más formal, sin la caricatura que, a veces, presenta Liera en Las fábulas perversas.

Es evidente que hay un escarnio constantemente dirigido, sobre todo, al poder, en este sentido, al eclesiástico y al político. En 1822 se muestra cómo la corrupción del Estado es un asunto tan viejo que, según el enfoque de este trabajo, tendría que ver con la formación de México como nación, mientras que en Las fábulas perversas los ataques irán dirigidos hacia los manejos deshonestos de la Iglesia. Lo similar, en este caso, es que ambas obras muestran los males endémicos que el gobierno y el clero han llevado como estandarte desde tiempos inmemoriales. El punto de partida es que la comicidad en Óscar Liera se da por las peculiaridades de sus personajes, a diferencia de González Mello, donde la hilaridad la obtenemos más por la agudeza del diálogo satírico. No obstante, en los dos dramaturgos la intención de lo risible no sólo se queda en eso, la intención es señalar la reflexión, la seriedad que estos pasajes nos han enseñado. Por lo que, en nuestro caso, para el lector/espectador de Liera y/o González Mello se evidencia que la misión de los autores no sólo era hacer reír y divertir con las ocurrencias de los personajes, sino llamar la atención hacia los vicios de nuestra historia, la cual continuamente es utilizada por los

Véase Genette, Gérard. Palimpsestos. La literatura en segundo grado. Madrid: Taurus, 1989, pp. 9- 44.

8 González Mello hace una crítica con 1822 al año 2000, época de transición de poderes en México, con la llegada del Partido Acción Nacional (PAN), después de la dictadura partidista del Partido Revolucionario Institucional (PRI). En el caso de Liera, su obra haría referencia al gobierno de Toledo Corro en su natal estado de Sinaloa. Es bien sabida la animadversión que el escritor sentía hacia el gobernador, en donde incluso le escribió una misiva, su famosa "Carta al Tigre", en la que da cuenta de la serie de abusos y vejaciones que este personaje cometía. Para conocer más de este texto, véase: Liera, Óscar. "Carta al Tigre". Paso de gato. Revista mexicana de teatro, año 1, núm. 6, 2003, pp. 6- 8. 
políticos para enarbolar su bandera principal: la ignorancia. La técnica de la parodia impulsa a comprender una nueva lectura; los gobiernos aprovechan la religión y el nacionalismo como instrumentos para dominar a la gente y mantenerla en obediencia. Mediante el acto de parodiar se trabaja por igual la burla y el homenaje; son las dos direcciones que hacen que el mensaje social funcione magistralmente, ya sea para mostrar un respeto o para potenciar la crítica. ${ }^{9}$

En el caso de 1822, la obra de González Mello, los personajes pudieran tener algo de caricatura, ciertamente, pero su orientación va más hacia la sátira. Por ejemplo, el personaje que interpreta a Guadalupe Victoria, quien primero funge como un salvaje patriota, y luego termina siendo un títere del gobierno, alguien sin carácter y todavía más risible que en su primera aparición. Lo interesante de los personajes de González Mello es que su exageración no los hace más ficticios, sino, en una suerte de coincidencia divertidísima, los vuelve más realistas: "MIER: Sobra; y si los monos supiesen hablar, bastaría que el Congreso fuera de ellos y dijeran que representaban a la Nación. Entre los hombres no se necesitan sino farsas, porque todo es una comedia. Seamos realistas, General..." (1822 86).

En otro orden de ideas, como ya se mencionó líneas atrás, Liera, en su obra, opta por hacer una representación paródica de la vida fray Servando; sin embargo, conviene puntualizar qué parodia Liera de la vida del padre Mier. Básicamente, la pieza es un resumen de los distintos avatares que este singular personaje protagonizó en la historia mexicana. No obstante, Liera toma, como instantes trascendentales, el momento del discurso sobre la Virgen de Guadalupe, así como la subsecuente persecución que fray Servando sufrió con las autoridades eclesiásticas y políticas. Asimismo, la parodia también se encarga de la situación histórica, donde se recrean distintos eventos de la vida del fraile, como sus múltiples arrestos y escapes de varias prisiones.

9 Aunque Las fábulas perversas es considerada como farsa por la crítica especializada y por el propio Liera, en nuestro caso queremos dedicarle más espacio a la parodia y a la sátira, por ser las encomiendas de este trabajo. Al respecto de la farsa, conviene citar las palabras de Armando Partida: "Liera ridiculiza despiadadamente a los representantes de la iglesia que casi los torna grotescos, tanto por su envoltura externa, como por sus actos y posiciones que sostienen entre sí mismos. La exageración llega al choteo, al cachondeo, de manera que la farsa, más que comedia, se torna en una bufonada. Esta última característica dramática es muy peligrosa, pues puede hacer que se equivoque el tono y la puntería hacia donde va dirigida la crítica. Es por ello que puede desaparecer, nulificarse si el tratamiento se engolosina con las características externas y evidentes de esta farsa, por lo que su contenido crítico puede neutralizarse al quedarse en un simple regodeo, en una simple chacota sobre los representantes de la iglesia" (13). Por otro lado, así explicaba Liera su forma de ver la farsa: "es un género que permite una exageración, un agrandamiento de lo cotidiano. Exagerando las situaciones, la actuación misma, podemos volver a tomar la sensibilidad de la gente" (citado en López Cruz 9). 
El primer elemento parodiado, sobre la vida de fray Servando, es el famoso sermón que pronunció el 12 de diciembre de 1794. Aquí citamos lo que apuntaba Liera en su tesis de licenciatura sobre este tema:

Mier, con gran osadía, dirá en su sermón que quien trajo la imagen de la Virgen de Guadalupe fue el mismo apóstol santo Tomás quien había ya predicado en América y que la imagen se hallaba pintada sobre la capa del apóstol y no en la tilma de Juan Diego. Lo que [la V]irgen (sic) había hecho con el indio era entregarle la pintura que ella misma había guardado. De esta manera los dos grandes mitos de México quedaban unidos como una nueva concepción dualista del antiguo México (Técnicas narrativas en las memorias de Fray Servando Teresa de Mier 26).

Dicha tesis también funge como un afortunado hipotexto de Las fábulas perversas, pues en este documento Liera retoma ciertos elementos críticos, como el ya citado sermón del padre Mier, sólo que en el teatro esto se ve ridiculizado con el planteamiento de los gallos y gallinas, vistos como entidades religiosas.

He aquí una de las diferencias principales que encontramos con el texto de Flavio González Mello, pues el fray Servando de 1822 está más acorde con el personaje histórico, en cuanto a las ideas y la voluntad que tenía de buscar una independencia de la Corona española. En la obra de Liera no hay un planteamiento claro de cómo el padre dominico pretendía fomentar, a través de su ideología, el progreso y desarrollo social, como ocurrió en la figura histórica. ¿Por qué no incluyó Liera esto en su parodia? ¿Por qué sólo se centró en la parte del discurso antiguadalupano? La respuesta puede ser por la necesidad personal de mostrar cómo, hace mucho tiempo, un hombre se atrevió a desafiar a todo un régimen, en este caso a la Iglesia y a la sociedad. Liera vio en la figura de fray Servando a un revolucionario adelantado a su tiempo, a un intelectual, y a un hombre que quiso cambiar el mundo sin más armas que las ideas. Por ello, la religión y su efecto nocivo en la gente es la parte en la que más se centra el autor sinaloense; por eso, insiste en mostrar cómo fue perseguido. Incluso, podría pensarse que Servando es una especie de álter ego del mismo Liera. En el fondo, esta postura del autor nos indica la otra vertiente contestataria que siempre siguió el dramaturgo culiacanense: su abierta posición contra la iglesia.

Esta representación de un hombre idealista y contestatario es una constante en el imaginario de Liera. Baste recordar a su Jesús Malverde en El jinete de la Divina Providencia; al Heraclio Bernal de Los caminos solos, y a Rafael Buelna, en El oro de la Revolución mexicana. Todos ellos fueron sujetos perseguidos, algunos por sus ideas más que otros, pero al final de cuentas perseguidos. 
Las bases falsas y burlonas de la Iglesia católica son las que denuncia Óscar Liera en su texto, pues resulta evidente el origen religioso, risible y pueril, en el que cae a veces la religión, según el autor. Aquí, Liera ya no ataca a la tradición en sí, sino a lo que le rodea; esto es, al fanatismo y a lo peligroso que resulta. En un interés singular, Liera desea que los oyentes-espectadores noten su discurso contra el fanatismo religioso y, sobre todo, lo ridículo y grave que puede ser. A diferencia de él, González Mello centra su crítica en la historia y su carácter circular. Se trata de un planteamiento más filosófico que ideológico, pues coloca a la historia como un continuum de eventos trágicos, que parecieran repetirse cada cuando en nuestro país.

Es preciso señalar que Liera no quería hacer una obra histórica nada más, sino también una parodia del personaje histórico; de hecho, su interés se centra en el presente que vivía el autor. La idea era hacer reflexionar al público y concientizarlo del daño que el fanatismo religioso, junto a la corrupción política, pueden llegar a propiciar. En este punto, es muy importante señalar que, tanto 1822 como Las fábulas perversas, pretenden proponer escenarios presentes, es decir, abordar problemáticas contemporáneas, aunque, eso sí, aprovechando a fray Servando como símbolo de protesta y rebeldía. Esto es más evidente en la obra de Liera, pues se da la indicación desde la didascalia:

El vestuario no corresponde a época alguna que nos pudiera dar a entender que se trata de un momento histórico determinado; la obra debe reflejar la realidad actual que no es más que una gran fábula perversa, pero tampoco el vestuario pertenece a nuestra época a excepción del hombre extraño, el cual viste de saco y corbata, aunque por lo general trae el saco en la mano y anda en mangas de camisa (Las fábulas perversas 120).

En el caso de 1822, las alusiones a la actualidad se dan de forma inferida e irónica y a través de los diálogos, tanto los de los personajes, como el diálogo que la obra entabla con el espectador:

MIER: (Lo mira fijamente.) ¿Marcha?... ¿Qué no es usted el que me trajo preso a la Inquisición hace cinco años, cuando lo de Mina?

MARCHA: ¿Yo?

MIER: Sí, sí. El que se jactaba de haberle dado el tiro de gracia a Morelos...

MARCHA: Bueno, yo...

MIER: Y de haber cortado las cabezas de Hidalgo y Allende para exhibirlas en la Alhóndiga. Marcha, sí... ¡Pío Marcha!

ITURBIDE: Está confundido, padre. El Coronel Marcha fue quien se encargó de quitar de la Alhóndiga las cabezas de nuestros próceres, terminando así con tan bochornoso espectáculo. 
MIER: Sí, sí, pero antes él mismo las había...

ItURbide: (Lo interrumpe.) Antes las cosas eran distintas. Hoy es tiempo de concordia. Todo rencor debe ser olvidado en aras de la Unión. Y quien no esté dispuesto puede irse a otro lado, porque aquí no vamos a tolerar nada que fomente la división (González Mello 40). ${ }^{10}$

En Las fábulas perversas hay una situación muy parecida, cuando Servando cuestiona a uno de los integrantes del "nuevo" gabinete:

SERVANDO: A este hombre yo lo descubrí. ¿Tú cómo decías en la obra?

GENERAL: Aquí órdenes y aquí contraórdenes.

SERVANDO: Extraordinario, eres un gran actor, siempre te he recordado y ahora con mucho cariño te felicito por tus méritos.

$[\ldots]$

SERVANDO: Esta revolución no debe llamarse revolución de la farsa, sino que se "gira" la orden de que se llama "Revolución de Noviembre". (Al general.)

¿Cuál era tu parlamento?

GENERAL: Aquí órdenes y aquí contraórdenes.

SERVANDO: (Al encargado del protocolo.) ¿Y tú qué decías?

ENCARGADO DEL PROTOCOLO: ¡Justicia del rey! (Servando se ríe solo y aplaude. Hay gran espectación (sic) entre todos los demás. La gente empieza a murmurar y a comentar que está loco, que ha perdido la razón. El Caudillo viene por Servando y lo lleva con él hasta el estrado.) (170).

Como se ve, en ambas piezas predomina la ironía cuando Servando/Mier inquieren a los villanos ahora convertidos en héroes. En los dos casos, hay una burla implícita por las "nuevas" autoridades, en cuanto que se cuestiona al pasado de estos sujetos y su relación con el antiguo régimen. Sin embargo, este cuestionamiento no sólo es para los personajes, sino también para nosotros como receptores; es decir, Liera y González Mello nos preguntan: ¿qué tan válidos son los nuevos gobiernos si están integrados por los mismos tiranos que se pretendía erradicar? No hay duda de que aquí ambos dramaturgos no sólo están pensando en el pasado, sino también en su época presente e, incluso, en la que vivimos hoy en día. Esta es una pista para comprender cómo las dos obras comparten una ideología muy similar, en el sentido que se plantea una enseñanza histórica, a través de aprender de momentos similares del pasado.

10 Las cursivas son mías. 
INVESTIGACIÓNTEATRAL

Revista de artes escénicas y performatividad

Vol. 11, Núm. 17

abril-septiembre 2020
La parodia, la sátira y la intertextualidad

Ricardo Torres Miguel

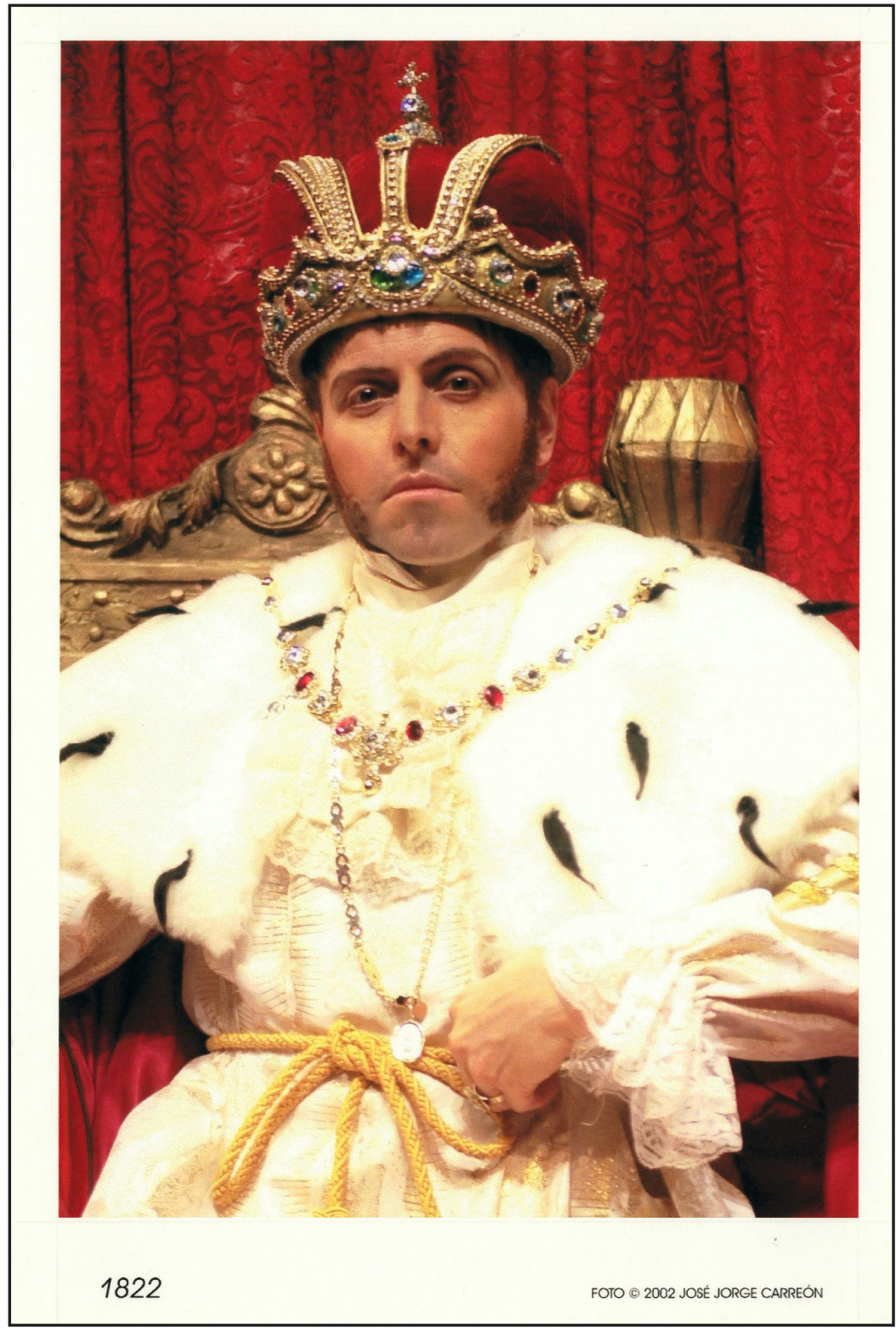

En una entrevista, el propio González Mello confiesa su intención de comparar su presente con la época post-independentista:

El elemento que le faltaba me lo dio el año 2000 cuando vino el momento del cambio político en el país, la salida del PRI y las elecciones donde finalmente ganó Vicente 
Fox. El proceso en ambos momentos históricos es igual: una transición. De alguna manera la obra habla sobre la situación actual reflejándola en un proceso, digamos, gemelo (De la Rosa 77).

Pareciera que estos procesos se repiten o tienen "gemelos", como dice González Mello, lo que significaría una historia cíclica, donde los eventos históricos tienden a suceder cada cierto tiempo, no de la misma manera, pero sí con circunstancias semejantes. Curiosamente, existe una respuesta similar por parte de Liera, respecto a la relación de la historia con la actualidad:

[...] es un pretexto para hablar de la época actual. Porque si digo que estoy hablando de antes de la revolución, criticando un sistema caduco, que no funciona, donde hay los vicios que existen actualmente en cuanto al modo de impartir justicia, la mala repartición de la riqueza, la política electoral... en realidad estoy hablando de la época actual (Partida 15).

Por supuesto, esto podría tomarse como una coincidencia; sin embargo, demuestra la voluntad por hablar de la historia como una visión panorámica y completa, pero al mismo tiempo reveladora.

Esta perspectiva de la historia como un ciclo de eventos paralelos es una de las posturas más recurrentes en la obra de González Mello. Lo usa tanto en 1822 como en Lascurain o la brevedad del poder, de 2006. La percepción del dramaturgo pareciera apuntar a un principio didáctico, donde se critica al pasado para aprender de él y no cometer el mismo error en el presente o para comprender mejor la actualidad que se vive. De cualquier manera, la conexión de 1822 con Las fábulas perversas radica en comparar hechos del pasado con momentos presentes, pues en ambas obras hay la intención de reflejar el México contemporáneo, ya sea a través de la parodia como lo hace Liera o de la sátira como con González Mello.

Como se comentó anteriormente, Liera pugna por deshacerse de una representación histórica. Le interesa que su receptor sienta todos los problemas que se muestran como cotidianos; por eso, la mirada del autor insiste en no enfocarse en ninguna época, aunque sabemos que esto es irónico. No obstante, el final de la obra parece indicar que se trata de la consumación de la Independencia, donde el factor antieclesiástico, nuevamente, es lo que más resalta: "El Caudillo: Sabemos que usted trató de negar la tradición del Gallo Secular y, aunque nosotros no somos religiosos, nos gusta respetar las creencias del pueblo..." (Las fábulas perversas 170).

Aunque hay elementos ficticios, en 1822 el factor histórico se muestra más exacto, por lo que aquí también se da una escena similar acerca del arrepentimiento por el sermón 
polémico de parte de fray Servando: "RAMOS ARIZPE: Mira... para que puedas rendir protesta, es indispensable que antes pronuncies unas palabras al pleno, retractándote de lo que dijiste hace treinta años en tu sermón de la basílica" (González Mello 32).

Esta aparente reconciliación es bastante parecida en Liera y González Mello. En las dos se plantea al padre Mier como un sujeto incómodo para el nuevo régimen, pero al mismo tiempo necesario, pues en aras de rendir homenajes a los héroes, se tiene que aceptar convivir con sus "defectos", en este caso, nada más y nada menos que la crítica al símbolo religioso del movimiento revolucionario.

La parodia en Las fábulas perversas funciona con situaciones cómicas y ridículas, como la alusión a los gallos, gallinas y gavilanes, vistos como dioses, vírgenes y diablos, o la escena llena de equívocos del rey impartiendo justicia al titiritero y su desaguisado con el licenciado. En este punto, el chacoteo llega a su punto más álgido:

TITIRITERO: Yo, majestad, soy un pobre titiritero que vive de su oficio y voy por todas partes llevando la alegría para que el pueblo siempre esté contento. Pues bien, majestad, tenía yo un hermoso gatito blanco que estaba aprendiendo a cantar y a hablar, y ya sabía decir las vocales, y ese hombre, majestad, que es un licenciado envidioso, le arrancó la lengua.

(Llora.)

REY: (Enloquece de cólera, grita y da vueltas.) ¡¿Cómo es posible?! ¿Y en mis dominios tal crueldad? (Se calma.) Bien; doy la orden de que a ese licenciado también le sea arrancada la lengua en castigo. (Exclamación del pueblo, el Rey toma una pose de dignidad.)

LICENCIADO: (En actitud implorante.) ¡Piedad, soberano mío, el titiritero no ha contado todo!

REY: No estoy dispuesto a oír más, estoy cansado.

LICENCIADO: (Insidioso.) ¿Aunque ese gato injuriara al Rey?

REY: (Colérico.) ¿Cómo? ¿Qué decía?

LICENCIADO: (Muy digno.) Sí, soberano mío, es verdad que yo le arranqué la lengua al gato ese, pero es que cada vez que decía las vocales las decía de esta manera: "a", el Rey es un tatán; "e”, el Rey es un tetén; “i”, el Rey es un titín; “o”... (135-136).

En el anterior diálogo fársico se advierte la astucia del pueblo contra la estupidez del monarca, como señalando que la gente es inteligente y algún día se las cobrará a los jerarcas. En González Mello hay un ejemplo totalmente contrario a lo que quiso mostrar Liera, pues aquí la voluntad de la comunidad se ve como equivocada: 
MIER: Pues hay que responderle lo que Jesucristo a los hijos de Zebedeo: nescitis quid petatis. "No saben lo que piden"... A veces es necesario contrariar la voluntad del pueblo para servirlo mejor. Sus diputados no somos recaderos; no eligieron a hombres más cultos que ellos para que les vayamos a consultar cada decisión. ¿Cómo van a decidir sobre lo que no conocen? Yo lo reto a que le pregunte a cualquiera de ellos qué casta de animal es esa república que no quieren tener, y apuesto mi pescuezo a que responden treinta mil desatinos (64).

En los últimos ejemplos, tomados de 1822 y Las fábulas perversas, se percibe más el aspecto ideológico de ambas obras, pues la de González Mello resalta más la voluntad por criticar el carácter y la ideología política de los personajes; en cambio, en Liera se respira una visión del poder a través de la burla. Sin embargo, a medida que la trama de Las fábulas perversas avanza, hay situaciones que dejan de ser cómicas y terminan por ser temas serios - por supuesto, esto es causado por el efecto de la parodia-; en lo subsecuente, la historia se conducirá por el sendero del mensaje crítico y en donde difícilmente se asome la risa.

En la obra de González Mello se muestra a un Mier receloso a la hora de retractarse del famoso sermón que lo condenó prácticamente a vivir en la rebeldía eterna:

RAMOS ARIZPE: Te estás metiendo en problemas.

MIER: ¡Bah! ¿Qué me puede pasar?

RAMOS ARIZPE: Que te encarcelen. Cuando menos.

MIER: No sería la primera vez.

RAMOS ARIZPE: ¿Eso quieres, verdad? ¡Volver a prisión!... En el fondo te encanta ser perseguido... ¿No puedes disentir de manera más respetuosa?

MIER: Sí, sí: se comienza por no abuchear, y al rato ya está uno aplaudiendo, primo (62).

En sintonía con lo dicho por Hutcheon y por lo visto hasta ahora, el tema intertextual desempeña un papel determinante en la comprensión de la dramaturgia de Liera y González Mello, pues en Las fábulas perversas se presentan temas, situaciones, símbolos que más adelante se volverán a tocar en 1822. Esto quiere decir, como afirma Linda Hutcheon citando a Riffaterre, que tenemos una memoria dialógica como lectores, que hace que converjan un texto anterior con uno actual (192).

Es evidente que hay una reescritura de algunas partes simbólicas en el texto de González Mello, sobre todo en el caso de los hombres que portan el poder en ambas obras; la diferencia es que en Las fábulas perversas se hiperbolizan más las actitudes [risibles] bufonescas de los personajes, mientras que en 1822 los personajes adquieren más una tonalidad satírica. 
Por el otro lado, en Las fábulas perversas la encomienda de Servando no es probar el mito religioso mediante herramientas científicas, sino, al contrario, relegarlo y concederle valor al verdadero creador del hecho milagroso: el hombre. Las afirmaciones de Servando, si bien pueden parecer contradictorias, responden a negar el valor del "Gallo", a cambio de restaurar el valor a la fe, pues según el protagonista, ésta es una condición intrínseca del ser humano y por la cual se han creado todas las fábulas que pregona la humanidad. Esto quiere decir que el personaje ficticio y paródico va más allá en sus disquisiciones sobre el mito de la aparición. La parodia propuesta por Liera reduce el evento milagroso a la burla; igualmente, lo hace con los reclamos de los patriarcas, pero en medio de todo este torbellino de hilaridad se propone un asunto serio, ¿de qué sirven los mitos y apariciones?, ¿quién los crea?, ¿con qué objetivo? Si es el individuo quien crea sus religiones, ¿no debería ser éste el principal sujeto de adoración?, es decir, ¿no debería ser el intelecto humano el principal objeto de adoración por todos como seres pensantes? El otro punto de crítica propuesto por Liera es la relación de la Iglesia con el Estado. En la trama, Servando, luego de ser apresado por los religiosos, enfrenta un juicio legal donde será condenado por el crimen de herejía.

Fiscal: Yo acuso, en nombre del pueblo y de la Gran Hermandad Universal del Gallo, al doctor Servando de haber negado categóricamente, en presencia del pueblo y en una solemnísima ceremonia, la tradición de nuestro Gallo Secular, padre del sol y hacedor del día. Con ello ha tratado de negar todo el conocimiento que nos legaron nuestros antepasados; lo más importante en el resumen de la experiencia de nuestra raza; y eso que la tradición es para nosotros es una garantía de verdad y, en este caso, la única, más grande y excelsa garantía. Eso es todo (Las fábulas perversas 127).

Negar la tradición le valió a fray Servando múltiples encierros y persecuciones prácticamente por todo el mundo hasta su vuelta a México. Ésta es una de las concordancias más notables entre la parodia de Liera y el padre Mier real. Tanto en la ficción dramática como en la vida real, Teresa de Mier no quería desestimar o negar la fe, lo único que quería era comprobar por el filtro de la verdad (científica) si la tradición era como la habían contado los primeros textos, es decir, fundamentar, por medio de argumentos, su tradición, superar los actos de fe en actos de verdad. Sin embargo, esta osadía llevaría al padre Mier a enfrentar un largo periplo hasta su casi "beatificación" por los líderes de la Independencia de México.

En 1822, también se toca el tema del famoso discurso y la supuesta negación de la Virgen de Guadalupe. Aquí también vemos la rebeldía del religioso y su ansia de duda que lo caracterizó toda su vida: 
RAMOS ARIZPE: Mira... para que puedas rendir protesta, es indispensable que antes pronuncies unas palabras al pleno, retractándote de lo que dijiste hace treinta años en tu sermón de la basílica.

MIER: ¿¿Retractarme?!

RAMOS ARIZPE: Es una pequeña formalidad. Sólo tienes que decir que te arrepientes de haber negado la existencia de la Virgen de Guadalupe.

MIER: ¡Yo nunca negué su existencia! Lo que negué fue la leyenda de las apariciones a Juan Diego, nada más.

GÓMEZ FARÍAS: ¡Nada más!

MIER: En mi sermón demostré que mucho antes de la Conquista, la Virgen ya era venerada por los antiguos mexicanos, y que la imagen no está impresa en el ayate de Juan Diego, sino en la capa de Santo Tomás Apóstol, que vino a predicar en estas tierras en el primer siglo de nuestra era y fue conocido con el nombre de Quetzalcóatl.

GÓMEZ FARÍAS: ¡Qué disparate! (32).

Sin embargo, en la obra de González Mello no se pone especial atención al tema del sermón, como sí sucede con la pieza de Liera. La diferencia de estos dos planteamientos radica en la postura antieclesiástica que siempre mostró el escritor sinaloense, no sólo en Las fábulas perversas, sino en gran parte de su producción teatral. En contraparte, 1822 trata de poner el dedo en la llaga en las formas de gobierno que se tuvieron en México, empezando por el debate de si era mejor nombrarse imperio o república.

Como se ha insistido a lo largo de este trabajo, Servando de Las fábulas perversas es una parodia del personaje revolucionario del siglo XVIII y XIX. Liera utiliza el efecto de la parodia para dialogar con su público, para darnos un mensaje: la historia de Iglesia y Estado ha estado coludida desde el inicio de la colonia de este país, la victoria al final, esto es la creación de una república sobre las bases de la dominación española, no vislumbrará buenos frutos, pues la conclusión de la obra nos dirá que se continuarán los mismos vicios y crímenes que se pretendían erradicar. En este sentido, el autor se inclina más hacia la historia que a la parodia; con esto, el final es desesperanzador, la negatividad que expone parece estar muy lejos de los momentos burlones del inicio:

Patriarca: Creo que he tenido una gran idea para el mejor lucimiento de esta solemnísima ceremonia que se está preparando. Traigo aquí nada menos que una hermosa pintura de nuestro Gallo Secular. Es una copia exacta del pendón que se usó como bandera en las luchas revolucionarias y creo que sería conveniente que presidiera la reunión de hoy, ya que es la primera recepción oficial que organiza la república y en reconocimiento a ése que se usó como primera bandera en nuestras luchas libertarias (Las fábulas perversas 168). 
INVESTIGACIÓNTEATRAL

Vol. 11, Núm. 17

abril-septiembre 2020
La parodia, la sátira y la intertextualidad

Ricardo Torres Miguel

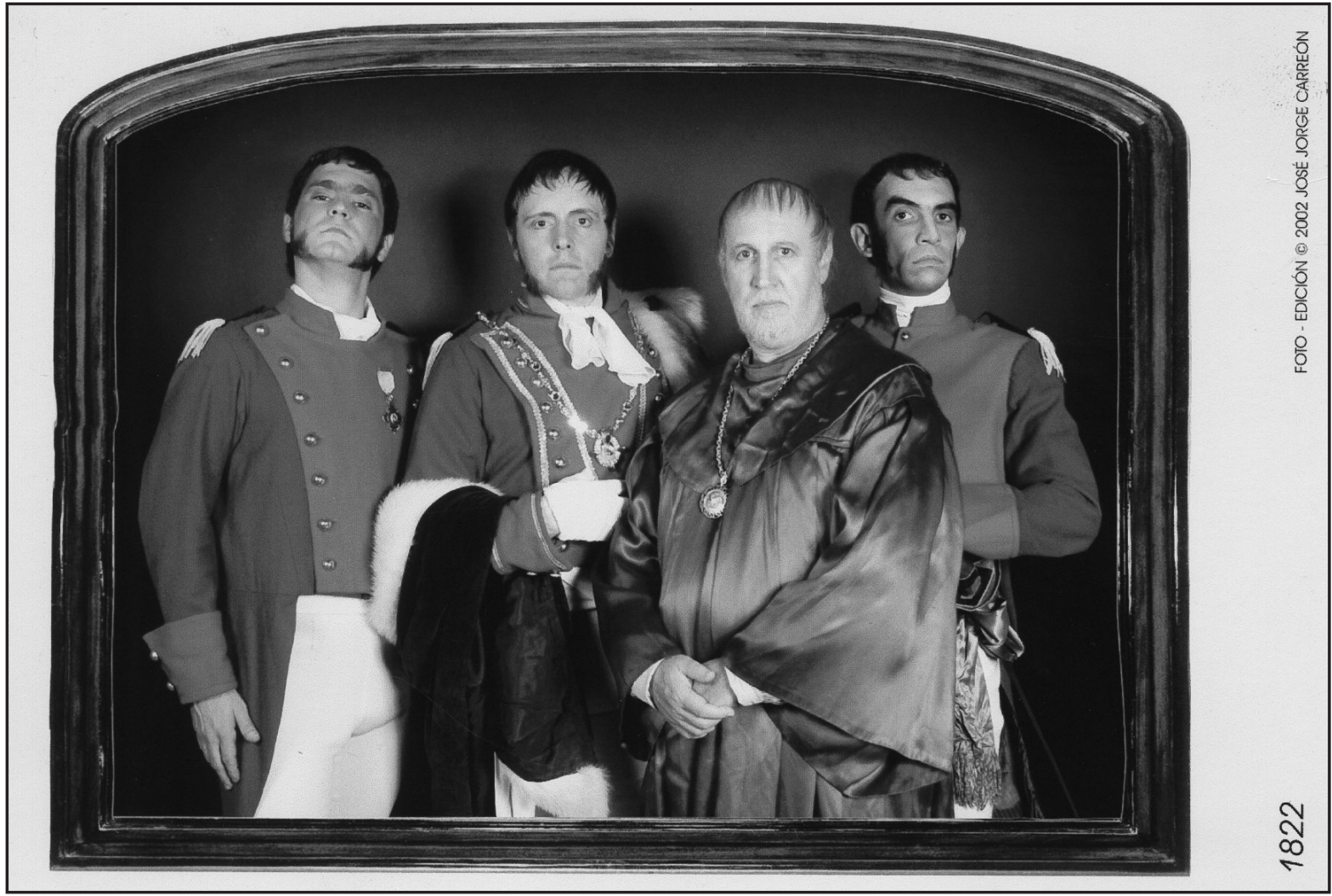

De izquierda a derecha: Martín Altomaro (Antonio López de Santa Anna), Mario Iván Martínez (Agustín de Iturbide), Héctor Ortega (Servando Teresa de Mier) y Hernán del Riego en 1822. El año que fuimos imperio. Foto cortesía del Archivo INBA/CITRU. Colección Fotográfica Coordinación Nacional de Teatro.

Como se ve, Liera condena los momentos en que la relación entre Iglesia y Estado se funden hasta crear uno solo. En un acto paródico evidente de la Independencia de México, Las fábulas perversas recrea ese instante donde se decide continuar con la religión de los conquistadores, tomarla como propia y, lo que es más, como representante directa de su movimiento armado.

Por otro lado, en 1822 también se anuncia una especie de mensaje desesperanzador cuando, en los diálogos entre Mier y Guadalupe Victoria, se vislumbra el futuro del país, comenzando por la eterna división entre facciones:

Victoria: Lo siento. Yo no puedo obedecer a un Congreso disuelto... con excepción del de Tehuacán, claro está. 
MIER. ¿Ese es el problema? Pues ahorita mismo formamos otro. Tener Congreso es el huevo Juanelo. Usted designa diputados a diez de sus hombres, y ellos a su vez lo nombran a usted Presidente. Y ya tenemos Congreso para autorizar sus acciones.

VICTORIA: No, para formar un Congreso legítimo y auténticamente representativo no basta con eso... (86).

Es curioso notar que ambos escritores pudieran entender la realidad histórica como una fábula, que se representa según las preferencias políticas de los que ostentan el poder. Esta visión del mundo de ambos dramaturgos es lo que puede dar una pista para comprender la postura ideológica que se tiene sobre el pasado y su relación con el México actual.

Por medio de la parodia, Liera representa los actos protocolarios de ceremonia para consumar la independencia. La obra combina historia, ficción y crítica en una sola exhibición, dejando al lector con un horizonte de expectativas bastante amplio, pues le deja el juicio de estos eventos totalmente a su gusto: "El lector que no logra captar la ironía (la parodia o la sátira) es aquel cuya expectativa es, de un modo u otro, insuficiente" (Hutcheon 188).

De acuerdo con esta lectura, Hutcheon señala que la parodia es una repetición, "un engarce de lo viejo con lo nuevo" (177), es decir, se puede afirmar que gran parte de las escenas paródicas de Las fábulas perversas intentan repetir los momentos históricos del célebre padre Mier, pero modificados por medio de la farsa, con el fin de provocar una reacción diferente en el espectador, es decir, buscar una reflexión sobre lo nocivas que pueden llegar a ser las enseñanzas eclesiásticas.

En contraparte, González Mello hace uso de la sátira para mostrarle al público lo falsa que suele ser la política, no sólo de la época independentista, sino la del México contemporáneo. La burla que provocan los personajes históricos hace que el receptor tome conciencia de las condiciones en que a veces puede caer un momento histórico, como lo fue el nacimiento de nuestro país:

VICTORIA: ¿Pero piensa que debo firmar?

MIER: ... Sin duda. Y cuanto antes, mejor.

Victoria: (Señala a Santa Anna.) Pero él también era realista.

MIER: General... creo que el fin superior que perseguimos amerita que olvidemos esas pasadas diferencias.

VICTORIA: Está bien. Todo sea por la... la... ¿cómo se llama, esto... lo que estamos intentando salvar...?

MIER: Pellejo, don Lupe (92). 
El ejemplo anterior es una clara advertencia para que el receptor entienda finalmente por qué se da todo este juego satírico entre los personajes. Conservar la vida para los políticos quizás sea una de las prerrogativas más importantes en las distintas etapas que ha atravesado la historia mexicana. Es, probablemente, el corolario ideal para entender por qué las ideas, a veces, trascienden a quienes las portan, es decir, los símbolos pueden permanecer incólumes; los hombres, no.

Sin embargo, el tema serio en 1822 siempre será visto con mesura, como si todo se tratase de una ironía, asunto que no sucede con Las fábulas perversas pues, como hemos visto, hay episodios donde la tragedia ronda constantemente, como el caso de las prisiones a Servando o, incluso, en los mismos diálogos de este personaje; en ocasiones, no se asoma el humor, más bien pareciera que emerge el rencor y el reclamo que siempre conservó Liera respecto a los temas de la iglesia. Por ello, es plausible pensar que ambas obras representan una comedia, pero con sus diferencias: en la pieza de Liera sobresale una versión antieclesiástica y en la de González Mello se pondera una crítica política.

En el caso de Las fábulas perversas, Servando trata de convencer a los demás de aceptar la posibilidad de ser uno, esto es, regirse por el libre albedrío, no por religiones y mitos que impiden el libre pensamiento. El personaje de Liera se ve como un ser obsesivo, rebelde y, por momentos, necio. Su misión de vivir sin religiones se ve frustrada al final de la obra, donde los victoriosos recurren nuevamente al mito de la Gallina para "estar con el pueblo". Mientras, el Mier de 1822, como vimos hace unos instantes, es un ser que disfruta vivir de los vacíos que tiene la política; trata de imponer su razón y eso lo lleva al hartazgo, con lo cual termina de forma muy similar y aludiendo, plenamente, al Servando de Las fábulas perversas. Ambos personajes terminan frustrados, viejos y amargados, dejándole al lector/espectador la decisión de calificarlos como lo crean conveniente. Esta última reflexión va muy en tono con lo que nos deja la parodia:

El discurso paródico es un discurso disidente; investido a priori de esta ideología de la contestación, su lugar se define siempre respecto del poder, cualquiera que sea. La parodia no ocupa ningún lugar propio, sino el que la sitúa frente al objeto de su rechazo (Pauls 7).

La crítica frontal que sobresale al final de ambas obras es una actitud mordaz, pues se da a entender que todo ha sido una burla perversa. ¿En qué puede convertirse una nación que ha nacido de la farsa? ${ }^{11} \mathrm{Al}$ final, en la pieza de Liera, el relator y Servando se funden para plasmar el mensaje final de la obra:

11 Es preciso mencionar que, en este caso, mencionamos farsa más en el sentido coloquial de la palabra que el teatral, aunque, como ya se dijo, la obra de Liera tiene mucho de este elemento. 
Servando: (Se adelanta un poco. Ríe con cierta amargura y luego la cara se le ilumina. Los susurros han alcanzado su más alto nivel.) Gracias, gracias, ustedes pueden llenarse de ataduras, si quieren, porque no están capacitados para aquilatar la libertad. Yo prefiero revivirla y disfrutarla... (Se encamina hacia el proscenio con lentitud. Los comentarios que en un principio fueron muy discretos en la sala, se han convertido casi en un escándalo. Algunos de los militares del estado mayor se dirigen violentamente hacia el Caudillo; éste les dice algo y ellos corren hacia Servando pero antes de llegar a él, a excepción del relator, se quedan inmóviles. El relator se dirige al público) (171).

Como una estructura circular, nuevamente se ve a Servando siendo atacado por sus detractores; pareciera que nada cambió y todo sigue igual como al principio de la obra. Las mismas autoridades que enjuiciaban al personaje parecen sólo haberse cambiado de máscara, para seguir con su cometido.

La obra 1822 termina de manera similar a Las fábulas perversas, cuando el padre Mier ejecuta un aparte y se dirige al público: "A los mexicanos les heredo una patria independiente y republicana, aunque infestada de parásitos y a punto de desmembrarse, para que se arreglen con ella lo mejor que puedan..." (114). Al igual que la obra de Liera, 1822 termina con la misma sensación de amargura, como si, a pesar de las diferencias, las dos piezas tuvieran la misma visión funesta del destino de México.

\section{Conclusiones}

Es evidente que hay alusiones directas en algunas partes de 1822 a Las fábulas perversas, sobre todo en la parte de la historia mexicana y la construcción de los personajes. De igual manera, también hay diferencias en el uso que Mello hace de la sátira y Liera de la parodia. Pero, también es notable que hay una memoria lectora que termina uniendo ambos textos, sobre todo en el sentido de partir de un ideologema en común para comunicarnos un mensaje. Así, la mirada retrospectiva al pasado, como educadora del presente, es la visión del mundo que comparten Liera y González Mello. Sus tramas, sus protagonistas, sus estructuras pueden tener semejanzas y diferencias, pero su voluntad de aprender del pasado es intrínsecamente relacionable. Éste es el principal legado que una obra de ficción histórica nos puede dejar: lograr que nuestra memoria y nuestra cultura lectora sean el motor para identificar al texto como parte de una red superior y prolongada de dramaturgia compartida, sincera y, sobre todo, comprometida con la verdad histórica (Camarero 43).

En definitiva, el uso que Liera propone de la parodia y Mello de la sátira determina en gran medida la visión del mundo que se plantean. A través de la risa, el equívoco y la si- 
tuación cómica, los personajes se dirigen a un derrotero más serio. La fábula de Servando, el padre intelectual de Liera, así como los diálogos irónicos y satíricos del padre Mier de González Mello, provocan a reflexionar lo que ha sido de México, en términos políticos, hasta nuestros días. Además, es como si el tiempo hubiera estado ausente y la misma historia siguiera representándose una y otra vez, dentro de una realidad tragicómica. Ésa es la enseñanza final de Las fábulas perversas y 1822: no hay pasado, ni presente si no hay aprendizaje; si se vuelve a reincidir y se cometen los mismos errores, no habrá progreso y se seguirá representando una misma fábula perversa.

\section{Agradecimientos}

A la doctora Lillian von der Walde Moheno sus valiosos comentarios y revisiones.

\section{Fuentes consultadas}

Barthes, Roland. "La muerte del autor". Textos de teorías y crítica literarias (Del formalismo a los estudios postcoloniales), selección y apuntes introductorios por Nara Araujo y Teresa Delgado. México: Universidad de la Habana/UAM-I, pp. 339-345.

Camarero, Jesús. Intertextualidad: redes de textos y literaturas transversales en dinámica intercultural. Rubí/Barcelona: Anthropos, 2008.

De la Rosa, Katia. "1822 el año que fuimos imperio. Entrevista a Flavio González Mello". Revista de la Universidad de México, núm. 14, 2005, pp. 76-81.

Genette, Gérard. Palimpsestos. La literatura en segundo grado. Madrid: Taurus, 1989, pp. 9- 44.

González Mello, Flavio. 1822. México: Ediciones El Milagro/Consejo Nacional para la Cultura y las Artes, 2004.

Hutcheon, Linda. "Ironía, sátira, parodia. Una aproximación pragmática a la ironía”. De la ironía a lo grotesco (en algunos textos literarios hispanoamericanos), editado por María Christen Florencia et al. Traducido por Pilar Hernández Cobos, México: Universidad Autónoma Metropolitana, 1992, pp. 173- 193.

Ivanov Mollov, Peter. "Problemas teóricos en torno a la parodia. El "apogeo" de la parodia en la poesía española de la época barroca”. Revista electrónica de estudios filológicos, núm. 11, 2006, www.um.es/tonosdigital/znum11/estudios/12-parodia.htm, consultado el 22 de octubre de 2013.

Kristeva, Julia. "Bajtín, la palabra, el diálogo y la novela”. Intertextualité: Francia en el origen de un término y el desarrollo de un concepto, editado por Desiderio Navarro. La 
Habana: Unión de Escritores y Artistas de Cuba/Casa de las Américas/Embajada de Francia en Cuba, 1997, pp. 1-24.

Latapí Escalante, Paulina. "El teatro histórico como ámbito educativo. Análisis de cuatro obras para conmemorar el triunfo de la República en Querétaro, México". Historia y Memoria, núm. 17, 2018, pp. 185-217, revistas.uptc.edu.co/index.php/historia_memoria/article/view/7438/6738, consultado el 20 de enero de 2020.

Leñero, Vicente. La nueva dramaturgia mexicana. México: Ediciones El Milagro/Consejo Nacional para la Cultura y las Artes, 1996.

Liera, Óscar. Las fábulas perversas. Teatro escogido. Prólogo de Armando Partida Tayzan. México: Fondo de Cultura Económica/Difocur, 2008, pp. 117-171.

Liera, Óscar. Técnicas narrativas en las memorias de Fray Servando Teresa de Mier. Tesis de licenciatura en Lengua y Literatura Hispánicas, Universidad Nacional Autónoma de México, 1982.

López Cruz, Sebastián ("Sebastián Liera”). Óscar Liera. Un luchador del teatro por el teatro mismo. México, Universidad Nacional Autónoma de México, pp. 1-9, es.scribd. com/doc/39354972/Oscar-Liera-un-luchador-del-teatro-por-el-teatro-mismo, consultado el 21 de agosto de 2011.

Luzón Marco, María José "Intertextualidad e interpretación del discurso". EPOS: Revista de filología, núm. 13, 1997, pp. 135-149.

Mendoza Fillola, Antonio. "El intertexto lector". Biblioteca Virtual Miguel de Cervantes, Fundación Biblioteca Virtual Miguel de Cervantes, www.cervantesvirtual.com/obra-visor/el-intertexto-lector-0/html/01e1dd60-82b2-11df-acc7-002185ce6064_2.html, consultado el 18 de enero de 2020.

Partida Tayzán, Armando. "Introducción". Pez en el agua, Óscar Liera. México: UAs, 1990, pp. 5-25.

Pauls, Alan. "Tres aproximaciones al concepto de parodia", Cecilia Maugeri, www.ceciliamaugeri.com.ar/tres-aproximaciones-al-concepto-de-parodia-por-alan-pauls/, consultado el 30 mayo de 2019. 